\section{Free access to hypertension and diabetes medicines among the elderly: a reality yet to be constructed}

\author{
Acesso gratuito a medicamentos para hipertensão \\ e diabetes em idosos: uma realidade \\ a ser construída
}

\footnotetext{
1 Programa de Pós-graduação em Epidemiologia,

Universidade Federal de Pelotas, Pelotas, Brasil.

2 Programa de Pós-graduação em Saúde Coletiva, Universidade do Vale do Rio dos Sinos, São Leopoldo, Brasil.

3 Programa de Pós-graduação em Saúde e Comportamento Universidade Católica de Pelotas, Pelotas, Brasil. 4 Secretaria Municipal de Saúde e Bem Estar de Pelotas, Pelotas, Brasil.

5 Faculdade de Enfermagem e Obstetrícia, Universidade Federal de Pelotas, Pelotas, Brasil.

6 Programa de Pós-graduação em Educação Física, Universidade Federal de Pelotas, Pelotas, Brasil.

Correspondence V. M. V. Paniz Programa de Pós-graduação em Saúde Coletiva, Universidade do Vale do Rio dos Sinos.

Av. Unisinos 950

São Leopoldo, RS 93022-000, Brasil. vpvieira@terra.com.br
}

\section{Abstract}

The study evaluated free access to hypertension and diabetes medicines and the reasons reported for lack of access. The sample included 4,003 elderly people living in Primary Care Unit coverage areas from 41 Southern and Northeastern Brazilian cities. Free access was higher in the Northeast (62.4\%). The strategy of the Family Health Program (Programa Saúde da Família - PSF) was more effective in providing access than the traditional model, with higher results in the Northeast (61.2\%) than in the South (39.6\%). Around 20\% of medicines included in the Hypertension and Diabetes Program and 26\% of those included in the National Essential Medicines List (RENAME) were paid out of pocket. In the Northeast, 25\% of insulin and $32 \%$ of oral antidiabetics were paid out of pocket. Unavailability in the public sector and a lack of money determined the lack of access. Although the PSF, Hypertension and Diabetes Program and RENAME expanded free access, supplies were insufficient. A greater connection between programs and a clear definition of responsibilities can improve medicine acquisition process, increasing the effectiveness of pharmaceutical assistance.

Continuous-Use Medicine; Free Distribution of Drugs; Pharmaceutical Services; Hypertension; Diabetes Mellitus
Vera Maria Vieira Paniz 1,2 Anaclaudia Gastal Fassa 1 Luiz Augusto Facchini 1 Roberto Xavier Piccini 1 Elaine Tomasi 3,4 Elaine Thumé 5 Denise Silva da Silveira 1,4 Maria Aparecida Rodrigues 1,4 Marlos Rodrigues Domingues 1,6 Andréa Dâmaso Bertoldi 2

\section{Introduction}

In Brazil, free and widespread access to essential medicines standardized by the Unified National Health System (SUS) is guaranteed under the Brazilian Constitution through Law 8080/90 (article 6) 1, assuring complete therapeutic assistance, including pharmaceutical assistance. However, studies evidence obstacles in the process of obtaining essential medicines from the primary health care system $2,3,4,5$, resulting in high medicine-related costs for the family 6,7 .

Because of an ageing population and an increase in chronic diseases, such as hypertension and diabetes mellitus, there is a growing demand for continuous-use medicines to treat such morbidities. After the establishment of the Family Health Program (PSF) strategy in 1994, health initiatives sought to link chronic patients to primary care units (PCU) for treatment and followup, promoting efficient and high-quality care 8 .

It is still a challenge to guarantee access to essential medicines, particularly in developing countries ${ }^{9}$. In 1998 the government approved the National Medicines Policy 10, based on Pharmaceutical Assistance Reorientation, in an attempt to promote access to and the rational use of medicines, along with the adoption of the National Essential Medicines List (RENAME), a list of medicines considered basic and indispensable for most population health problems. RENAME is supposed to be the foundation for essential 
medicines lists at state and local level, and should also guide the standardization, prescription and supply of medicines, mainly within SUS 11.

Besides these guidelines, other programs were established aiming to provide access to essential medicines within the SUS, such as the National Program of Pharmaceutical Assistance to Arterial Hypertension and Diabetes Mellitus 12 . The National Strategy for the Reorganization of Arterial Hypertension and Diabetes Mellitus Care implements, through this Program, the register and follow-up of hypertensive and diabetic patients detected by SUS and the free supply of five essential medicines: captopril $25 \mathrm{mg}$, hydroclorotiazide $25 \mathrm{mg}$ and propranolol $40 \mathrm{mg}$ for hypertension treatment; glibenclamide $5 \mathrm{mg}$ and metformin $850 \mathrm{mg}$ for diabetes treatment, as well as NPH-100 insulin systematically distributed within the public health service 13 through the Program of Strategic Medicines 14.

National publications about household-level medicine access are scant, the methodologies employed vary, access is measured regardless of consumption conditions 15,16,17,18 and some studies exclude chronic patients 14 . Other studies have evaluated medicine access based on the availability of medicine in health services 2,3,4,5,19. In spite of different methods, population studies using 15-day recall period report medicine access ranging from $87 \%$ to $96 \% 14,15,16$. A study among elderly people from São Paulo city, Brazil, found a slightly lower access $-82.7 \%$ - during the previous year 17. National data show low levels of free access among the Brazilian population, between $11 \%$ and $38.3 \% 14,17,20,21,22$. Using as the denominator chronic-disease medicines, a Southern Brazil study found free access to be $66 \%$ regardless of the source of the medication, and $63 \%$ when considering only free medicine from the PSF/SUS 15.

The present study evaluated free access to hypertension and diabetes mellitus continuous-use medicines, among the elderly living in PCU coverage areas from the South and Northeast Brazil, according to type of PCU, morbidity to which the medicines were indicated, its inclusion in the Hypertension and Diabetes Program or in the RENAME (http://www.anvisa.gov.br) and pharmacologic groups. In addition, the study identified the reasons reported for the lack of access to medicines.

\section{Methods}

A cross-sectional study was carried out between March and August, 2005, in two distinct Brazilian regions, including 7 states and 41 cities with more than 100,000 inhabitants. The methodology employed was originally designed for the baseline study of the Project for the Expansion and Consolidation of the Family Health Program Strategy (PROESF) in South and Northeast Brazil (component 2) 23, comprising the states of Rio Grande do Sul and Santa Catarina in the South region and Alagoas, Paraíba, Pernambuco, Piauí and Rio Grande do Norte, in the Northeast region, as regulated by the Brazilian Ministry of Health 24 .

The target population of the study was elderly people (65 or older), living in PCU coverage areas, who were able to respond to the questionnaire. Subjects were sampled by a multi-stage process that considered the PCU as the primary sampling units, using probability proportional to the structural capacity of the primary care networks of each city. Each lot comprised 120 PCUs randomly selected, according to the type of PCU, totaling 240 PCUs. In Brazil, there are two types of PCU: (1) traditional units are those that were established before 1994, when the PSF was established and (2) PSF units are those in which the PSF strategy was established. From here onwards, this variable will be referred to as "type of PCU", and the two categories will be denominated as traditional and PSF. PROESF demanded a sample size of 2,100 elderly. This sample divided by the 120 selected PCU resulted in a quota of 18 elderly being interviewed at each service coverage area 23 .

The sampling of selected individuals was done systematically and independently, using the PCU as the starting point. The area covered by each selected PCU was defined, and the interviewer visited consecutive households, interspersing the elderly interview with three other population groups evaluated by PROESF, including only one person from each household, alternating the gender of interviewees. When two elderly people were living in the same house, the oldest was interviewed. More details of the study design can be found elsewhere 23 .

The need for continuous-use medicines was defined as: the need for taking the medicine every day, or most days, without defining a specific date for stopping. Access was evaluated among people responding "yes" to questions about having hypertension and or diabetes and the need for continuous-use medicine, as indicated by a doctor, to treat these morbidities. To assure the accuracy of the medicine registry, and to avoid skipping (omitting) medicines consumed, interviewers were instructed to ask for the prescription, packet and/or directions for use. For each medicine reported, subjects were asked the following question about access: "During the last month have you skipped the use of [name of med- 
icine] you needed?" When the response was positive, the reason why the medicine was not taken was asked: "Why did you not take the medicine?" and the choices were: did not want to, forgot to; it was not available at the PCU of the area; it was not available in another PCU/SUS pharmacy; could not afford it; prescription expired; another reason. If the elderly person did not skip the use of his/her medicine during the last month, the mode of acquisition was asked along with the place where the medicine was obtained for free, using the question: "Did you get the [medicine name] for free?" and choices were: did not get it; yes, at the PCU of the area; yes, another PCU; yes, SUS pharmacy; yes, elsewhere.

The results were analyzed using two different approaches. First, in order to evaluate access, the denominator was the total number of elderly people (measured by the number of people taking medicine in the last month), free access (elderly people given medicine for free, regardless of place) and free access at the PCU of the area (people acquiring their medicine for free at the PCU of the area). Medicine access was categorized as follows: total access (person did not skip the use of any needed medicines); partial (person skipped the use of some needed medicines, regardless of the reason) and no access (person skipped the use of all needed medicines, regardless of the reason) and evaluated according to the investigated region and type of PCU (PSF and traditional).

The second approach considered as the denominator the number of medicines reported by the population. In this analysis the medicines were identified according to the Pharmaceutical Specialties Dictionary 25 and categorized according to reported morbidity (hypertension and/or diabetes), included or not in the Hypertension and Diabetes Program, in RENAME 2002, valid during data collection and in pharmacologic groups according to the Anatomical Therapeutic Chemical Classification System 26. Two levels of the system were used: the first representing the main anatomical group and the second, considering the main therapeutic group.

Data were entered in Epi Info 6.04 (Centers for Disease Control and Prevention, Atlanta, U.S.A) and analyses were carried out using Stata 9.0 (Stata Corp., College Station, U.S.A). Different access patterns were estimated for each indicator evaluated. To study associations between regions and access among the elderly, 95\% confidence intervals $(95 \% \mathrm{CI})$ were estimated. Chi-square tests for proportions heterogeneity were used to compare access among people from different types of PCU and to evaluate potential differences in the mode of access to medicines included in the Hypertension and Diabetes Program and RENAME.
The design effect was considered during association analyses. A quality control was carried out by telephone with $6 \%$ of the sample who answered a short version of the questionnaire 23 . Agreement was measured by kappa index for the reporting of hypertension and diabetes, which presented a good repeatability (kappa $\geq 0.70$ ).

The research was approved by the Ethics Committee of the Medical School of the Federal University of Pelotas. All subjects agreed to participate before the interviews. Confidentiality was assured to all participants as well as the right to not take part or to drop out at any moment.

\section{Results}

A total of 4,003 elderly people were interviewed (South: 1,891; Northeast: 2,112), corresponding to $95.3 \%$ of the estimated sample (South: $90,1 \%$; Northeast: $100 \%)$. Out of which, 2,460 (61.5\%) reported that they had hypertension and/or diabetes and needed continuous-use medicine, totaling 4,563 reported medicines and 47 active principles.

The sample size studied in the South ( $\mathrm{n}=$ $1,164)$ and Northeast $(n=1,296)$, allowed to estimate, with $95 \%$ confidence level for each region, $90 \%$ access to continuous-use medicine with a margin of error of \pm 1.7 percentage points. It also permitted to estimate a free access, and free access at the PCU of the area of $50 \%$ with a margin of error of \pm 4.5 percentage points, considering a design effect of 1.03 for access, 2.14 for free access and 3.19 for free access at the PCU of the area.

Figure 1 classifies the 4,563 continuous-use medicines mentioned by the elderly to treat hypertension and diabetes, according to reported disease, inclusion in RENAME and Hypertension and Diabetes Program. The most commonlymentioned medicines were for treating hypertension (84\%) and belonged to RENAME (around 87\% hypertension and diabetes medicines). The Hypertension and Diabetes Program covered $65 \%$ of antihypertensive medicines and $76.1 \%$ of diabetes medicines. Among hypertension medicines not included in the Hypertension and Diabetes Program, $64.6 \%$ belong to RENAME. Among diabetes medicines not included in the Hypertension and Diabetes Program, $44.8 \%$ are included in RENAME.

Table 1 shows the characteristics of access to continuous-use medicines for the evaluated morbidities in the elderly population $(n=2,460)$ living in PCU coverage areas from the South and Northeast, according to type of PCU. Access to reported medicines and free access at the PCU of the area was significantly different in studied 


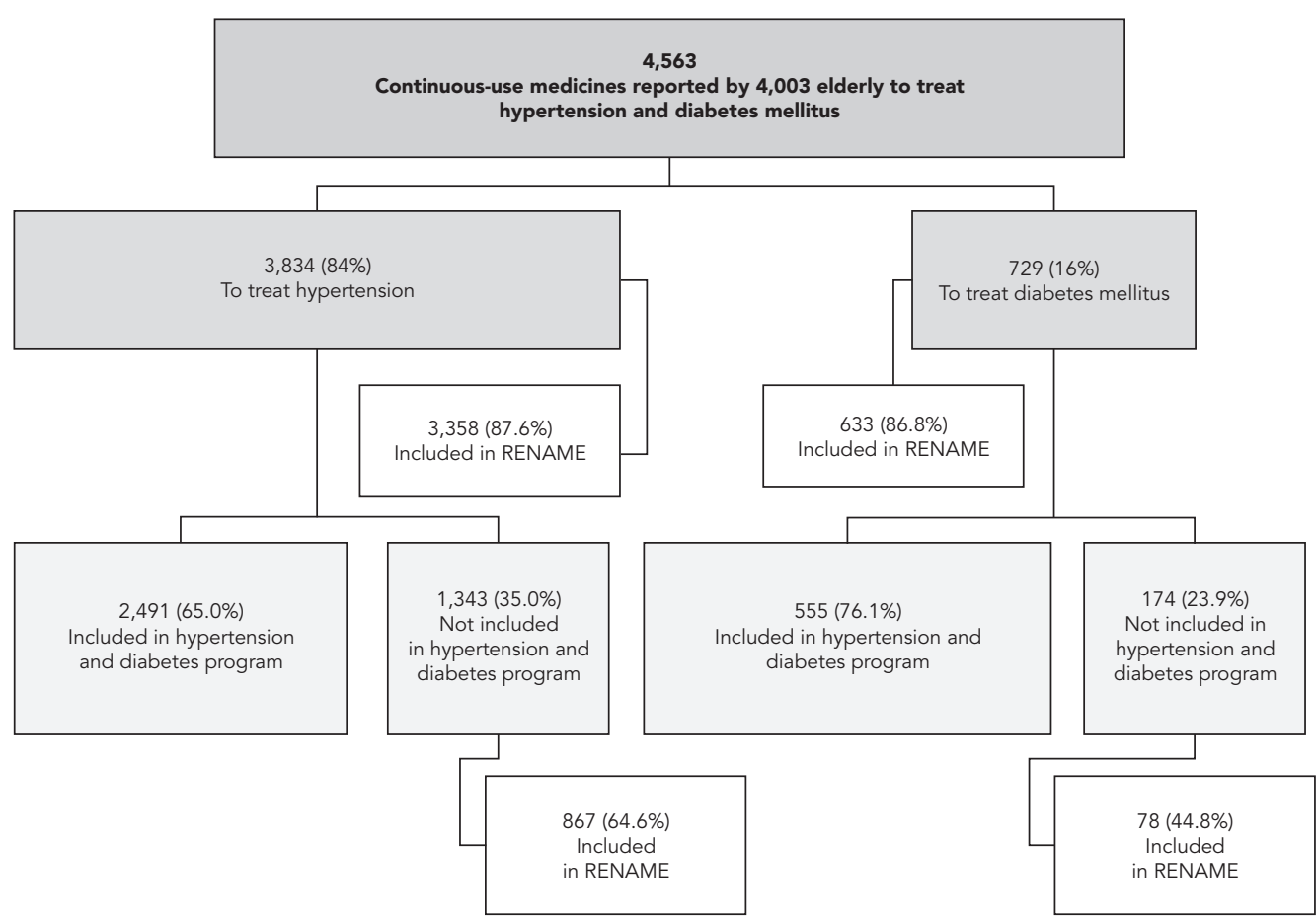

Note: the classification was done according to reported disease, inclusion in the National Essential Medicines List (RENAME) and in the National Program of Pharmaceutical Assistance to Arterial Hypertension and Diabetes Mellitus.

regions. Reported access to all medicines was higher in the South - 92.6\% (95\%CI: 91.0-94.2) than in the Northeast $-89.7 \%$ (95\%CI: 88.1-91.4) $(p=0.025)$. However, free access and free access at the PCU of the area were higher in the Northeast $(\mathrm{p}<0.001)$. Overall total free access was $55.1 \%$ (95\%CI: 51.0-59.2) in the South and $62.4 \%$ (95\%CI: 58.2-66.5) in the Northeast, while total free access at the PCU of the area was just $36 \%$ (95\%CI: 30.8-41.1) in the South, reaching 54.1\% (95\%CI: 49.5-58.6) in the Northeast.

Table 1 also shows that, in the South region, access to all reported medicines was similar regardless of type of PCU ( $p=0.495)$. This was quite the opposite to what was found in the Northeast, where access was significantly different between type of PCU ( $p=0.030)$, presenting higher access among the elderly living in PCU/PSF coverage areas (91\%) compared to those living in PCU/ traditional coverage areas $(86.6 \%)$. When free access in the South is evaluated, data shows that it was significantly higher in areas with PCU/PSF
(59.2\%) compared to PCU/traditional (48.9\%) $(\mathrm{p}<0.001)$. The same happens in the Northeast, where total free access was equal to $66.1 \%$ in areas assisted by PCU/PSF and $52.2 \%$ in areas assisted by the traditional type $(\mathrm{p}<0.001)$. Examining how the PCU of the area influences medicine access, one concludes that in both regions the $\mathrm{PCU} / \mathrm{PSF}$ are mostly responsible for free access ( $p<0.001$ ), with $39.6 \%$ of elderly in the South and $61.2 \%$ in the Northeast obtaining their medicines from the PCU/PSF of the area.

Table 2 shows the profile and mode of access to the medicines according to: Hypertension and Diabetes Program, RENAME and pharmacologic group in the South $(n=2,298)$. People did not have access to nearly $5 \%$ of continuous-use medicines, regardless of referred morbidity, and inclusion in the Hypertension and Diabetes Program or RENAME. As for pharmacologic groups, highest access was observed for beta-blockers (98\%) and lowest for renin-angiotensin system agents (94.6\%). 
Description of access to continuous-use medicines to treat hypertension and diabetes mellitus in the elderly population living in Primary Care Unit (PCU) coverage areas from the South $(n=1,164)$ and Northeast $(n=1,296)$. Project for the Expansion and Consolidation of the Family Health Program Strategy (PROESF), Brazil, 2005.

\begin{tabular}{|c|c|c|c|c|c|c|c|c|c|}
\hline \multirow[t]{2}{*}{ Access * } & \multicolumn{4}{|c|}{ South region } & \multicolumn{4}{|c|}{ Northeast region } & \multirow{2}{*}{$\begin{array}{c}\text { Between } \\
\text { regions } \\
\text { (p-value) ** }\end{array}$} \\
\hline & $\begin{array}{c}\text { Overall } \\
\%\end{array}$ & $\begin{array}{c}\text { PCU/traditional } \\
\%\end{array}$ & $\begin{array}{c}\text { PCU/PSF } \\
\%\end{array}$ & $\begin{array}{l}\text { Type of PCU } \\
\text { (p-value) ** }\end{array}$ & $\begin{array}{c}\text { Overall } \\
\%\end{array}$ & $\begin{array}{c}\text { PCU/traditional } \\
\%\end{array}$ & $\begin{array}{c}\text { PCU/PSF } \\
\%\end{array}$ & $\begin{array}{l}\text { Type of PCU } \\
\text { (p-value) } * \star\end{array}$ & \\
\hline Access & $\mathrm{n}=1,164$ & $n=456$ & $n=708$ & & $n=1,296$ & $n=357$ & $\mathrm{n}=939$ & & \\
\hline Total & 92.6 & 93.2 & 92.2 & 0.495 & 89.7 & 86.6 & 91.0 & 0.030 & 0.025 \\
\hline Partial & 2.6 & 2.9 & 2.4 & & 4.3 & 4.8 & 4.2 & & \\
\hline None & 4.8 & 4.0 & 5.4 & & 5.9 & 8.7 & 4.9 & & \\
\hline Free access & $n=1,107$ & $n=438$ & $n=669$ & $<0.001$ & $n=1,217$ & $n=326$ & $\mathrm{n}=891$ & $<0.001$ & $<0.001$ \\
\hline Total & 55.1 & 48.9 & 59.2 & & 62.4 & 52.2 & 66.1 & & \\
\hline Partial & 12.8 & 10.1 & 14.7 & & 13.1 & 9.8 & 14.3 & & \\
\hline None & 32.1 & 41.1 & 26.2 & & 24.6 & 38.0 & 19.6 & & \\
\hline Free access at the & $n=1,107$ & $n=438$ & $n=669$ & $<0.001$ & $n=1,217$ & $n=326$ & $\mathrm{n}=891$ & $<0.001$ & $<0.001$ \\
\hline \multicolumn{10}{|l|}{ PCU of the area } \\
\hline Total & 36.0 & 30.4 & 39.6 & & 54.1 & 34.7 & 61.2 & & \\
\hline Partial & 9.6 & 6.4 & 11.7 & & 12.4 & 7.1 & 14.4 & & \\
\hline None & 54.5 & 63.2 & 48.7 & & 33.5 & 58.3 & 24.5 & & \\
\hline
\end{tabular}

PCU/traditional: traditional primary care units; PCU/PSF: primary care units in which the Family Health Program strategy was established.

* Maximum missing values was 3 for variables "free access" and "free access at the PCU of the area";

** Chi-square test for heterogeneity of proportions.

From all medicines obtained, 35.1\% were paid out of pocket; $42 \%$ were received at the PCU of the area and $22.9 \%$ were received free of charge at a different PCU, SUS pharmacy or by other manners. Half of the diabetes medicines and only $40.4 \%$ of antihypertensive medicines were obtained free of charge at the PCU of the area. From all medicines covered by the Hypertension and Diabetes Program, 23\% were not freely supplied and $50.8 \%$ were supplied by the PCU of the area. However, $39 \%$ of reported medicines are not covered by the Hypertension and Diabetes Program and most of them $(53.9 \%)$ were bought $(\mathrm{p}<$ 0.001) (Table 2).

With respect to the mode of access to medicines included in RENAME, $27.9 \%$ were bought out of pocket and, among those obtained free of charge $(72.1 \%)$, two thirds were supplied by the PCU of the area. As for the reported pharmacologic groups, among cardiovascular medicines, highest free access was verified for diuretics $(65.2 \%)$ and renin-angiotensin system agents (70.4\%). However, $51 \%$ of beta-blockers and $55 \%$ of calcium channel blockers were not obtained for free. In terms of the pharmacologic group that acts on metabolism, $11.4 \%$ of insulin used in diabetes treatment and a quarter of oral antidiabetics were purchased (Table 2).
Table 3 presents access characteristics and modes of acquisition according to studied variables, in the Northeast $(n=2,265)$. A lack of access to medicines reported by the elderly was around $7 \%$. Proportionally, access to antihypertensive medication was the highest $(98.4 \%)$ while more than $7 \%$ of beta-blockers and renin-angiotensin system agents were not consumed by the elderly in the last 30 days.

As for the mode of acquisition of medicines in the Northeast region, more than half $(60.7 \%)$ were supplied by the PCU of the area, $30.4 \%$ were paid and only $9 \%$ were obtained free of charge at different PCUs, an SUS pharmacy or by other means. Most medicines for hypertension $(61.5 \%)$ and diabetes (56.2\%) were acquired free of charge at the PCU of the area. Only $15.8 \%$ of medicines included in the Hypertension and Diabetes Program were paid out of pocket and $75 \%$ were obtained at the PCU of the area. Considering the amount of medicines not included in the Hypertension and Diabetes Program (28\% of reported medicines), more than two thirds were purchased ( $\mathrm{p}<0.001$ ) (Table 3 ).

Table 3 also shows that $76.8 \%$ of medicines included in RENAME were acquired free of charge in the Northeast region, of which $88.1 \%$ were obtained at the PCU of the area. Among the 
Access characteristics and mode of access to continuous-use medicines to treat hypertension and diabetes mellitus reported by elderly people living in primary care unit (PCU) coverage areas in the South region. Project for the Expansion and Consolidation of the Family Health Program Strategy (PROESF), Brazil, 2005.

\begin{tabular}{|c|c|c|c|c|c|}
\hline \multirow[t]{4}{*}{ Variable * } & \multirow{4}{*}{$\begin{array}{c}\text { Total } \\
\text { n }\end{array}$} & \multirow{4}{*}{$\begin{array}{c}\text { Access } \\
\\
\%\end{array}$} & \multicolumn{3}{|c|}{ Mode of access ** } \\
\hline & & & \multirow{3}{*}{$\begin{array}{c}\text { Payment } \\
\\
\%\end{array}$} & \multicolumn{2}{|c|}{ Free } \\
\hline & & & & \multirow{2}{*}{$\begin{array}{c}\text { PCU of the area } \\
\%\end{array}$} & \multirow{2}{*}{$\begin{array}{c}\text { Another place } \\
\%\end{array}$} \\
\hline & & & & & \\
\hline Medicines reported by 1,164 people & 2,298 & 95.5 & 35.1 & 42.0 & 22.9 \\
\hline \multicolumn{6}{|l|}{ Chronic disease } \\
\hline Hypertension & 1,921 & 95.5 & 37.4 & 40.4 & 22.2 \\
\hline Diabetes & 377 & 95.8 & 23.3 & 50.4 & 26.3 \\
\hline \multicolumn{6}{|l|}{ Hypertension and Diabetes Program *** } \\
\hline Yes & 1,406 & 95.0 & 23.0 & 50.8 & 26.2 \\
\hline No & 892 & 96.4 & 53.9 & 28.4 & 17.7 \\
\hline \multicolumn{6}{|l|}{ RENAME } \\
\hline Yes & 1,990 & 95.4 & 27.9 & 47.4 & 24.7 \\
\hline No & 308 & 96.4 & 81.1 & 7.8 & 11.2 \\
\hline \multicolumn{6}{|l|}{ Pharmacologic groups \# } \\
\hline \multicolumn{6}{|l|}{ Cardiovascular System } \\
\hline Antihypertensives & 97 & 97.9 & 40.4 & 40.4 & 19.2 \\
\hline Beta-blockers & 252 & 98.0 & 51.0 & 27.1 & 21.9 \\
\hline Calcium channel blockers & 187 & 96.8 & 55.0 & 25.6 & 19.4 \\
\hline Diuretics & 696 & 94.7 & 34.8 & 43.9 & 21.3 \\
\hline Renin-angiotensin system agents & 689 & 94.6 & 29.6 & 45.9 & 24.5 \\
\hline \multicolumn{6}{|l|}{ Metabolism } \\
\hline Human Insulin (regular and NPH) & 45 & 97.8 & 11.4 & 43.2 & 45.5 \\
\hline Other oral antidiabetic medicines & 332 & 95.5 & 24.9 & 51.4 & 23.7 \\
\hline
\end{tabular}

RENAME: National Essential Medicines List.

Note: the chi-square test for proportions heterogeneity from the association between Hypertension and Diabetes Program/ RENAME and mode of access presented p-value $<0,001$.

* Maximum missing values was 3 for variable "mode of access";

** The denominator in the variable "Mode of access" considers only people reporting access;

*** National Program of Pharmaceutical Assistance to Arterial Hypertension and Diabetes Mellitus (covers five medicines: captopril, hydroclorotiazide, propranolol, glibenclamide, metformin);

\# Categorized according to levels 1 and 2 of the Anatomical Therapeutic Chemical Classification System 26.

pharmacologic groups studied, most cardiovascular medicines were obtained free of charge at the PCU of the area, except for calcium channel blockers that were mostly paid out of pocket (79.8\%). The figures for the metabolism pharmacological group are exceptional, since one quarter of insulin and more than $30 \%$ of oral antidiabetics were not obtained free of charge.

When we compare the access patterns for each region studied, as shown in Tables 2 and 3, it can be observed that lack of access was higher in the Northeast, but free access was also higher. In addition, in the Northeast, the PCUs of the area were responsible for the supply of three quarters of medicines included in the Hypertension and Diabetes Program, while in the South only half of these medicines were available to users. Access to RENAME medicines in the Northeast was also mostly obtained through the PCU of the area, while in the South free access to a quarter of the list's medicines occurred elsewhere. Calcium channel blockers was the pharmacologic group that presented the lowest levels of free access in both regions, lower in the Northeast where only $20 \%$ was supplied by the public health service. It is also noteworthy that in the Northeast the 
Access characteristics and mode of access to continuous-use medicines to treat hypertension and diabetes mellitus reported by elderly people living in primary care unit (PCU) coverage areas in the Northeast region. Project for the Expansion and Consolidation of the Family Health Program Strategy (PROESF), Brazil, 2005.

\begin{tabular}{|c|c|c|c|c|c|}
\hline \multirow[t]{4}{*}{ Variable * } & \multirow{4}{*}{$\begin{array}{c}\text { Total } \\
\text { n }\end{array}$} & \multirow{4}{*}{$\begin{array}{c}\text { Access } \\
\\
\%\end{array}$} & \multicolumn{3}{|c|}{ Mode of access ** } \\
\hline & & & \multirow[t]{2}{*}{ Payment } & \multicolumn{2}{|c|}{ Free } \\
\hline & & & & PCU of the area & Another place \\
\hline & & & $\%$ & $\%$ & $\%$ \\
\hline Medicines reported by 1,296 people & 2,265 & 93.6 & 30.4 & 60.7 & 9.0 \\
\hline \multicolumn{6}{|l|}{ Chronic disease } \\
\hline Hypertension & 1,913 & 93.5 & 30.1 & 61.5 & 8.4 \\
\hline Diabetes & 352 & 94.0 & 31.6 & 56.2 & 12.2 \\
\hline \multicolumn{6}{|l|}{ Hypertension and Diabetes Program *** } \\
\hline Yes & 1,640 & 93.7 & 15.8 & 75.0 & 9.2 \\
\hline No & 625 & 93.3 & 68.6 & 23.0 & 8.4 \\
\hline \multicolumn{6}{|l|}{ RENAME } \\
\hline Yes & 2,001 & 93.5 & 23.2 & 67.6 & 9.2 \\
\hline No & 264 & 94.3 & 83.9 & 8.4 & 7.6 \\
\hline \multicolumn{6}{|l|}{ Pharmacological groups \# } \\
\hline \multicolumn{6}{|l|}{ Cardiovascular system } \\
\hline Antihypertensives & 61 & 98.4 & 37.3 & 47.5 & 15.3 \\
\hline Beta-blockers & 221 & 92.8 & 37.8 & 51.5 & 10.8 \\
\hline Calcium channel blockers & 132 & 97.7 & 79.8 & 17.8 & 2.3 \\
\hline Diuretics & 787 & 93.3 & 25.3 & 66.5 & 8.2 \\
\hline Renin-angiotensin system agents & 712 & 92.8 & 22.8 & 68.7 & 8.5 \\
\hline \multicolumn{6}{|l|}{ Metabolism } \\
\hline Human Insulin (regular and NPH) & 33 & 93.9 & 25.8 & 41.9 & 32.3 \\
\hline Other oral antidiabetic medicines & 319 & 94.0 & 32.2 & 57.7 & 10.1 \\
\hline
\end{tabular}

RENAME: National Essential Medicines List.

Note: the chi-square test for proportions heterogeneity from the association between Hypertension and Diabetes Program/ RENAME and Mode of access presented p-value $<0,001$.

* Maximum missing values was 8 for variable "mode of access";

** The denominator in the variable "mode of access" considers only people reporting access;

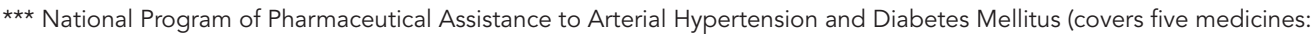
captopril, hydroclorotiazide, propranolol, glibenclamide, metformin);

\# Categorized according to levels 1 and 2 of the Anatomical Therapeutic Chemical Classification System 26.

proportion of medicines bought to treat diabetes was higher than in the South.

Table 4 shows the reasons for lack of access to continuous-use medicine during the previous month. For nearly one third of reported medicines, the unavailability of medicines in the SUS and unaffordability were the reasons for lack of access. In the Northeast, unavailability at the PCU of the area resulted in $26.2 \%$ of lack of access to the medicine.

\section{Discussion}

This study revealed a high access to continuoususe medicines prescribed for chronic diseases among the elderly. In the Northeast, where access was lower, free access was more common As for type of PCU, the PSF was more effective in providing free access than the traditional type of PCU, especially in the Northeast.

When access was evaluated using as denominator medicines reported by the elderly, it could be observed that the Hypertension and Diabetes Program and RENAME enhanced free access, having a greater impact over the North- 
Reasons for lack of access to continuous-use medicines to treat hypertension and diabetes mellitus reported by the elderly $(N=2,460)$ living in primary care unit (PCU) coverage areas from the South $(n=103)$ and Northeast $(n=145)$. Project for the Expansion and Consolidation of the Family Health Program Strategy (PROESF), Brazil, 2005.

\begin{tabular}{|c|c|c|c|c|}
\hline \multirow[t]{2}{*}{ Reasons for lack of access } & \multicolumn{2}{|c|}{ South } & \multicolumn{2}{|c|}{ Northeast } \\
\hline & $\mathbf{n}$ & $\%$ & $\mathbf{n}$ & $\%$ \\
\hline Did not want to, forgot & 46 & 44.7 & 72 & 50.0 \\
\hline Not available at the PCU of the area & 12 & 11.7 & 38 & 26.2 \\
\hline Could not afford & 11 & 10.7 & 14 & 9.7 \\
\hline Could not find it in another unit, SUS pharmacy & 9 & 8.7 & 1 & 0.7 \\
\hline Expired prescription & 6 & 5.8 & 2 & 1.4 \\
\hline Different reasons & 19 & 18.5 & 18 & 12.4 \\
\hline
\end{tabular}

SUS: Unified National Health System.

Note: chi-square test for heterogeneity of proportions between regions presented p-value $=0.001$.

east region. In both regions, the medicines that implied in the highest expenses for the elderly were calcium channel blockers indicated for the treatment of hypertension, however, a lower free supply of diabetes medicines was observed in the Northeast, especially insulin. The unavailability of medicines in SUS and lack of money to buy them were key determinants of a lack of access.

The cross-sectional design is appropriate to estimate access to medicines and to evaluate pharmaceutical assistance provided to the population in need of continuous-use medicine. This population approach allowed for the measurement of access to continuous-use medicine, regardless of visits to the doctors. The sample selected represents the population living in the PCU coverage area of the regions studied and internal validity is reinforced by the low missing rate based on the estimated sample size 23 .

As for the investigation period, studies on medicine access usually rely on 15-day 15 or 12 -month recall periods $17,27,28$. Other studies have evaluated access since the last visit to a doctor 16,29 , medical appointment in the last 15 days 14 or 30 days 22 . Because this study deals with continuous-use medicine, the choice was to investigate medicine access in the last month. To reduce the chance of recall bias, the medical prescription, packet or directions for use were requested, regardless of elderly access status.

The high levels of access to continuous-use medicine to treat chronic diseases in elderly people was similar to other national studies; despite the use of different approaches 14,15,16. The lower access observed in the Northeast along with a higher free access indicates that, in that region, the access relies on the free supply of medicines in the public sector. It corroborates the results of other analyses from the same research, showing the importance of socioeconomic aspects in the South. In the Northeast, the type of PCU and link with the PCU of the area are more important to establish access 30 .

It is interesting that this study found low free access among people living in PCU coverage areas in both regions, a finding that was corroborated by a Brazilian study in 11 cities, showing that only $55.4 \%$ of the 61 medicines investigated were available in public health services 2 . However, measuring access based on the amount of medicines in stock at health services reveals important aspects of pharmaceutical care, but it does not show the amount of patients unable to obtain all prescribed medicines. Availability is measured by having at least one medicine sample in stock, which, frequently, does not translate into a patient's treatment. Besides, Naves \& Silver 4 observed that despite having in stock $83.2 \%$ of the 40 key-medicines evaluated, interruption of hypertension or diabetes medicine supplies was frequent.

The proportion of elderly obtaining all medicines free of charge at the PCU of the area was higher under the PSF, compared with the traditional type of PCU, although both were similarly small. A study from São Paulo identified that only $42.2 \%$ of hypertensive and/or diabetic PSF users obtained all medicines at the PCU/PSF where they are being followed-up ${ }^{31}$. Moreover, from the $57.8 \%$ not obtaining the medicine, $83.8 \%$ bought and $5.4 \%$ did not consume the medicine until it was supplied free of charge. However, another study among a PSF-covered population in South Brazil, considering reported medicines as the 
denominator, showed that $80 \%$ of hypertension and diabetes medicines, and $88 \%$ of medicines prescribed by PSF doctors, were supplied free of charge in the PSF/SUS 15.

Although access to medicines under the Hypertension and Diabetes Program was higher than others, many were not obtained free of charge and, in the South, free supply occurred in an important amount out of the PCU of the area. Insufficiency of Hypertension and Diabetes Program medicines on primary health care may indicate flaws in the process of planning, purchasing, stocking or distributing these medicines. A 19-cities study carried out in the State of Minas Gerais, Brazil, found low availability of glibenclamide (21.4\%) in public health units, denoting a need for the Brazilian Ministry of Health to evaluate the procurement and distribution of this medicine to the state health departments and thereafter the planning and delivering to the cities ${ }^{3}$. A study carried out in the Federal District of Brazil, found that, in public health services, two medicines included in the Hypertension and Diabetes Program, captopril and metformin, were, respectively, second and sixth in the list of non-dispensed medicines ${ }^{4}$. A national-level study also found inadequate coverage of hypertension and diabetes medicines in PCU/PSF 32 The Hypertenses and Diabetics Information System (http://hiperdia.datasus.gov.br) associates the medicine supply to the number of registered patients. Therefore, incomplete or outdated information on the Hypertension and Diabetes Program may result in a shortage of these medicines in primary health care.

An aspect that must be highlighted is that many medicines that are not included in the Hypertension and Diabetes Program are listed on RENAME and, therefore, should be available to the population. However, more than $80 \%$ of medicines prescribed belong to RENAME, indicating high essentiality in this study, although one quarter were not obtained free of charge. The importance of paid access to essential medicines is reinforced by the study showing that $60.6 \%$ of medicines not available at the PCU belonged to RENAME 4 and by another study which observed that $75 \%$ of medicines consumed by the elderly were acquired in the private sector despite the fact that $27 \%$ of those were considered essential 6

According to the World Health Organization (WHO), pharmaceutical assistance is considered effective when $100 \%$ of prescriptions are based on the RENAME. However, tailoring prescriptions to the lists is not usual in the public sector, since many studies have reported distinct rates, ranging from $57.7 \%$ to $92.7 \% 4,5,14,19,33,34,35,36,37$.
This study adopted RENAME as the essentiality parameter, as suggested by a national survey ${ }^{2}$. In spite of the autonomy of the states to develop their own lists, these must be guided by the RENAME 14. Besides, this strategy was chosen due to the broadness of the study, including seven states and 41 cities, and also because some places did not have the local reference list, which would increase data analysis complexity. However, comparisons of our findings to WHO indicators must be considered with some caution, since a previous study carried out in the south of Brazil revealed that most $(82,4 \%)$ medicines prescribed were included in the local reference list, but only $57.7 \%$ belonged to RENAME 35 .

As for pharmacologic groups, it was verified that even first-choice medicines indicated for hypertension treatment, such as diuretics and betablockers, are commonly acquired through out of pocket payments. Paid access was even higher than a previous study carried out in the south of Brazil 15. A São Paulo study, carried out in 2003, revealed that $62.6 \%$ of individuals reporting hypertension and currently consuming medicine have paid for their treatment 21 . A national survey found an affordability of only two days for the treatment of hypertension among adults in the private sector ${ }^{14}$. This result highlights the impact that these costs might have over chronic-disease patients who cannot get their medicines free of charge.

Focusing on medicines indicated for diabetes treatment, the proportion of insulin that was not provided free of charge is striking, mainly in the Northeast, where population affordability is lower, depending hugely on free supplies. Free access to oral antidiabetics was also lower in the Northeast, in agreement with a study showing that insulin was unavailable in stock at health services of three out of eleven cities investigated and metformin was unavailable in all services of the four studied cities 2 .

The unavailability of medicine from the public sector and a lack of money to pay for it were among the main reasons for the lack of access. Medicine cost is the most frequent reason in many studies that evaluated reasons for lack of access $14,16,17,18$. However, in our study, the most frequent reason for not using medicine corresponded to the response "did not want to, forgot". Although this answer might be related to non-adherence to the treatment, this choice eventually included people facing other access barriers not detailed by the instrument, potentially resulting in an information bias impairing interpretation of this result.

In conclusion, the study found low free access for all cardiovascular and metabolism-re- 
lated pharmacologic groups, and for medicines belonging to the Hypertension and Diabetes Program and to the RANAME. It probably occurs because budget and medicine acquisition sources belong to various programs that use different financial policies leading to a significant overlap. The responsibility for medicines purchase is unclear. Besides, some aspects of the National Medicines Policy, were not fully accomplished, such as development of municipal lists, or specific programs, like the patients' register of the Hypertension and Diabetes Program. This impairs effective pharmaceutical assistance. In an attempt to solve these problems, the national-level medicine supply system is being decentralized. This strategy aims to make the process of medicine acquisition more suitable for local needs, thereby decreasing overlaps.

However, for the improvement of pharmaceutical assistance it is not appropriate to simply transfer responsibility to municipal authorities.
There is a need for an adequate medicine selection when preparing local and state standardized lists to guide physician's prescriptions, with periodic updates and tailoring to the health needs of local populations. It is also necessary to have a medicine acquisition strategy that is able to attend health service demand. In programs such as the Hypertension and Diabetes Program, planning not only involves gathering and registering hypertensive and diabetic individuals, in primary health care, but also constant updates of the information system. Improved planning will have greater impact in all other stages of pharmaceutical assistance.

Better links in the pharmaceutical assistance influenced by better integration among existent programs, avoiding program overlaps and promoting a clear definition of responsibilities, will optimize the medicine acquisition process at ambulatory level increasing the effectiveness of government strategies in the health sector.

\section{Resumo}

O estudo avaliou o acesso gratuito a medicamentos para hipertensão e diabetes e os motivos para a falta de acesso. A amostra incluiu 4.003 idosos residentes na área das unidades básicas de saúde (UBS) de 41 municípios do Sul e do Nordeste brasileiro. O acesso gratuito foi maior no Nordeste (62,4\%). O Programa Saúde da Família (PSF) teve mais impacto sobre o acesso que o modelo tradicional, sendo maior no Nordeste $(61,2 \%)$ que no Sul (39,6\%). Cerca de 20\% dos medicamentos do Programa Nacional para Hipertensão Arterial e Diabetes Mellitus e 26\% da Relação Nacional de Medicamentos Essenciais (RENAME) foram pagos. No Nordeste, $25 \%$ da insulina e $32 \%$ dos antidiabéticos orais foram pagos. Indisponibilidade no setor público e falta de dinheiro foram determinantes da falta de acesso. Embora o PSF, o Programa Nacional para Hipertensão e Diabetes e a RENAME ampliem o acesso gratuito, o suprimento foi insuficiente. Maior integração entre programas e clara definição de responsabilidades podem otimizar a aquisição de medicamentos, aumentando a efetividade da assistência farmacêutica.

Medicamentos de Uso Contínuo; Distribuição Gratuita de Medicamentos; Assistência Farmacêutica; Hipertensão; Diabetes Mellitus 


\section{Contributors}

V. M. V. Paniz participated in the literature review, project and data collection design, training of supervisors, quality control, data processing and analysis and write up and revision of the final article. A. G. Fassa participated in the project design, data analysis and write-up and revision of the final article. D. S. Silveira, E. Thumé, E. Tomasi, R. X. Piccini and L. A. Facchini participated in the study design, preparation of instruments, field work coordination, database preparation and revision of the final article. M. A. Rodrigues contributed to the design of instruments, data processing and review of the final article. M. R. Domingues contributed to the writing up and revision of the final article. A. D. Bertoldi collaborated in the project design, data analysis and writing up of the manuscript.

\section{References}

1. Brasil. Lei no .8 .080 , de 19 de setembro de 1990 . Dispõe sobre as condições para promoção, proteção e recuperação da saúde, a organização e o funcionamento dos serviços correspondentes e dá outras providências. Diário Oficial da União 1990; 20 set.

2. Karnikowski MG, Nobrega OT, Naves JO, Silver LD. Access to essential drugs in 11 Brazilian cities: a community-based evaluation and action method. J Public Health Policy 2004; 25:288-98.

3. Guerra Jr. AA, Acurcio FA, Gomes CA, Miralles M, Girardi SN, Werneck GA, et al. Disponibilidade de medicamentos essenciais em duas regiões de $\mathrm{Mi}$ nas Gerais, Brasil. Rev Panam Salud Pública 2004; 15:168-75.

4. Naves JOS, Silver LD. Evaluation of pharmaceutical assistance in public primary care in Brasília, Brazil. Rev Saúde Pública 2005; 39:223-30.

5. Santos V, Nitrini SMOO. Indicadores do uso de medicamentos prescritos e de assistência ao paciente de serviços de saúde. Rev Saúde Pública 2004; 38:819-26.

6. Lima MG, Ribeiro AQ, Acurcio FA, Rozenfeld S, Klein CH. Composição dos gastos privados com medicamentos utilizados por aposentados e pensionistas com idade igual ou superior a 60 anos em Belo Horizonte, Minas Gerais, Brasil. Cad Saúde Pública 2007; 23:1423-30.

\section{Acknowledgments}

The study is enrolled in Component 3 of the Project for the Expansion and Consolidation of the Family Health Program Strategy (PROESF), was supported by the Brazilian Ministry of Health and the World Bank, and received financial support from Coordinating Division for Graduate Studies (CAPES) and from the National Research Council (CNPq).
7. Lima-Costa MF, Barreto SM, Giatti L. Condições de saúde, capacidade funcional, uso de serviços de saúde e gastos com medicamentos da população idosa brasileira: um estudo descritivo baseado na Pesquisa Nacional por Amostra de Domicílios. Cad Saúde Pública 2003; 19:735-43.

8. Secretaria de Políticas de Saúde, Departamento de Atenção Básica. Programa Saúde da Família: informe técnico institucional. Rev Saúde Pública 2000; 34:316-9.

9. Romero CP. Reforma del sector salud y la política farmacéutica en Perú. Cad Saúde Pública 2002; 18:1121-38.

10. Ministério da Saúde. Portaria GM nº. 3.916, 30 de outubro de 1998. Aprova a Política Nacional de Medicamentos. Diário Oficial da União 1998; 10 nov.

11. Departamento de Atenção Básica, Secretaria de Políticas de Saúde, Ministério da Saúde. Política Nacional de Medicamentos. Brasília: Ministério da Saúde; 2001.

12. Ministério da Saúde. Portaria GM n ${ }^{\circ}$. 371, de 4 de março de 2002. Institui o Programa Nacional de Assistência Farmacêutica para Hipertensão Arterial e Diabetes Mellitus, parte integrante do Plano Nacional de Reorganização da Atenção à Hipertensão Arterial e ao Diabetes Mellitus. Diário Oficial da União 2002; 6 mar. 
13. Secretaria da Saúde, Secretaria de Políticas Públicas. Plano de reorganização da atenção à hipertensão arterial e ao diabetes mellitus. Rev Saúde Pública 2001; 35:585-8.

14. Ministério da Saúde, Organização Pan-Americana da Saúde, Organização Mundial da Saúde. Avaliação da assistência farmacêutica no Brasil: estrutura, processo e resultados. Brasília: Ministério da Saúde; 2005.

15. Bertoldi AD, Barros AJD, Wagner A, Ross-Degnan D, Hallal PC. Medicine access and utilization in a population covered by primary health care in Brazil. Health Policy 2008; 89:295-302.

16. Carvalho MF, Pascom ARP, Souza-Júnior PRB, Damacena GN, Szwarcwald CL. Utilization of medicines by the Brazilian population, 2003. Cad Saúde Pública 2005; 21 Suppl 1:S100-8.

17. Carvalho MFC. A polifarmácia em idosos no município de São Paulo: Estudo SABE - Saúde, Bem-estar e Envelhecimento [Dissertação de Mestrado]. São Paulo: Universidade de São Paulo; 2007.

18. Lebrão ML, Laurenti R. Saúde, bem-estar e envelhecimento: o estudo SABE no Município de São Paulo. Rev Bras Epidemiol 2005; 8:127-41.

19. Cunha MCN, Zorzatto JB, Castro LLC. Avaliação do uso de medicamentos na Rede Pública Municipal de Saúde de Campo Grande/MS. RBCF, Rev Bras Ciênc Farm 2002; 38:215-27.

20. Costa AA, Moura AAC, Mangueira JL, BarbosaBranco A. O uso de medicamentos pelas famílias atendidas no Centro de Saúde 8 do Gama-DF. Comun Ciênc Saúde 2007; 18:117-27.

21. Souza JJG. Hipertensão arterial referida e uso de anti-hipertensivos em adultos na cidade de São Paulo, 2003: em estudo de base populacional [Dissertação de Mestrado]. São Paulo: Universidade de São Paulo; 2006.

22. Fernandes MEP. A utilização de medicamentos na atenção à saúde, em nível domiciliar, no Município de Fortaleza [Dissertação de Mestrado]. Fortaleza: Universidade Federal do Ceará; 1998.

23. Facchini LA, Piccini RX, Tomasi E, Thumé E, Teixeira VA, Silveira DS, et al. Avaliação de efetividade da Atenção Básica à Saúde em municípios das regiões Sul e Nordeste do Brasil: contribuições metodológicas. Cad Saúde Pública 2008; 24 Suppl 1:S159-72.

24. Ministério da Saúde. Termo de referência para o estudo de linha de base nos municípios selecionados para o componente 1 do PROESF. Brasília: Ministério da Saúde; 2004.

25. Dicionário de especialidades farmacêuticas: DEF 2004/05. 33ạ Ed. Rio de Janeiro: Editora de Publicações Científicas; 2004.

26. World Health Organization. Anatomical Therapeutic Chemical (ATC) classification index with Defined Daily Doses (DDD's). Geneva: World Health Organization; 2004.
27. Reed M. An update on Americans' access to prescription drugs. Issue Brief Cent Stud Health Syst Change 2005; (95):1-4.

28. Piette JD, Heisler M, Wagner TH. Cost-related medication underuse among chronically ill adults: the treatments people forgo, how often, and who is at risk. Am J Public Health 2004; 94:1782-7.

29. Tediosi F, Aye R, Ibodova S, Thompson R, Wyss K. Access to medicines and out of pocket payments for primary care: evidence from family medicine users in rural Tajikistan. BMC Health Serv Res 2008; 8:109.

30. Paniz VMV, Fassa AG, Facchini LA, Bertoldi AD, Piccini RX, Tomasi E, et al. Acesso a medicamentos de uso contínuo em adultos e idosos nas regiões Sul e Nordeste do Brasil. Cad Saúde Pública 2008; 24:267-80.

31. Paiva DCP, Bersusa AAS, Escuder MML. Avaliação da assistência ao paciente com diabetes e/ou hipertensão pelo Programa Saúde da Família do Município de Francisco Morato, São Paulo, Brasil. Cad Saúde Pública 2006; 22:377-85.

32. Costa DMN. Atuação do SUS no controle da hipertensão arterial: a experiência de Juiz de Fora [Tese de Doutorado]. Rio de Janeiro: Universidade do Estado do Rio de Janeiro; 2006.

33. Simões MJS, Falvo IF. Estudo da prescrição de medicamentos para idosos atendidos em serviço público de saúde, em município da região sudeste, Brasil 1999. Rev Ciênc Farm 2000; 21:217-27.

34. De Bernardi CLB, Bieberbach EW, Thomé HI. Avaliação da assistência farmacêutica básica nos municípios de abrangência da 17ạ Coordenadoria Regional de Saúde do Rio Grande do Sul. Saúde Soc 2006; 15:73-83.

35. Colombo D, Santa Helena ET, Agostinho ACMG, Didjurgeit JSMA. Padrão de prescrição de medicamentos nas unidades de Programa de Saúde da Família de Blumenau. RBCF, Rev Bras Ciênc Farm 2004; 40:549-58.

36. Farias AD, Cardoso MAA, Medeiros ACD, Belém LF, Simões MOS. Indicadores de prescrição médica nas unidades básicas de Saúde da Família no município de Campina Grande, PB. Rev Bras Epidemiol 2007; 10:149-56.

37. Marcondes NSP. A assistência farmacêutica básica e o uso de medicamentos na zona urbana do $\mathrm{Mu}$ nicípio de Ponta Grossa, Paraná: estudo de caso [Tese de Doutorado]. Rio de Janeiro: Escola Nacional de Saúde Pública, Fundação Oswaldo Cruz; 2002.

Submitted on 16/Jan/2009

Final version resubmitted on 09/Dec/2009

Approved on 07/Jan/2010 